Article

\title{
Acuminatol and Other Antioxidative Resveratrol Oligomers from the Stem Bark of Shorea acuminata
}

\author{
Norhayati Muhammad ${ }^{1}$, Laily B. Din ${ }^{1}$, Idin Sahidin ${ }^{2}$, Siti Farah Hashim ${ }^{3}$, Nazlina Ibrahim ${ }^{3}$, \\ Zuriati Zakaria $^{4}$ and Wan A. Yaacob ${ }^{1, *}$
}

1 School of Chemical Sciences and Food Technology, Faculty of Science and Technology, Universiti Kebangsaan Malaysia, UKM Bangi 43600, Selangor D.E., Malaysia;

E-Mails: norhayatimuhammad@ymail.com (N.M.); lbdin@ukm.my (L.B.D.)

2 Faculty of Mathematics and Natural Sciences, Haluoleo University, Kendari 93232, Sulawesi Tenggara, Indonesia; E-Mail: sahidin02@yahoo.com

3 School of Biosciences and Biotechnology, Faculty of Science and Technology, Universiti Kebangsaan Malaysia, UKM Bangi 43600, Selangor D.E., Malaysia;

E-Mails: farah_samura@yahoo.com (S.F.H.); nazlina@ukm.my (N.I.)

4 Malaysia-Japan International Institute of Technology, Universiti Teknologi Malaysia Kuala Lumpur, Jalan Semarak, Kuala Lumpur 54100, Malaysia; E-Mail: zuriz@ic.utm.my

* Author to whom correspondence should be addressed; E-Mail: wanyaa@ukm.my; Tel.: +603-8921-5424; Fax: +603-8921-5410.

Received: 1 June 2012; in revised form: 10 July 2012 / Accepted: 18 July 2012 / Published: 30 July 2012

\begin{abstract}
A new resveratrol dimer, acuminatol (1), was isolated along with five known compounds from the acetone extract of the stem bark of Shorea acuminata. Their structures and stereochemistry were determined by spectroscopic methods, which included the extensive use of 2D NMR techniques. All isolated compounds were evaluated for their antioxidant activity using the 2,2-diphenyl-1-picrylhydrazyl (DPPH) radical scavenging activity (RSA) and the $\beta$-carotene-linoleic acid (BCLA) assays, and compared with those of the standards of ascorbic acid (AscA) and butylated hydroxytoluene (BHT). All compounds tested exhibited good to moderate antioxidant activity in the DPPH assay $\left(\mathrm{IC}_{50} \mathrm{~S} 0.84\right.$ to $10.06 \mathrm{mM}$ ) and displayed strong inhibition of $\beta$-carotene oxidation $\left(\mathrm{IC}_{50} \mathrm{~S} 0.10\right.$ to $0.22 \mathrm{mM}$ ). The isolated compounds were evaluated on the Vero cell line and were found to be non-cytotoxic with $\mathrm{LC}_{50}$ values between 161 to $830 \mu \mathrm{M}$.
\end{abstract}


Keywords: Dipterocarpaceae; Shorea acuminata; resveratrol oligomer; acuminatol; antioxidant activity; cytotoxicity

\section{Introduction}

Plants from the Dipterocarpaceae, Gnetaceae and Vitaceae families are known as rich sources of resveratrol oligomers [1]. There have been reports of 275 new resveratrol oligomers from these species between 1995 and 2008 [2]. Many studies have suggested that these groups of constituents exhibited a range of biological activities [3] which included antioxidant [4-8], antimicrobial [9], anti-inflammatory [10], anti-hepatotoxicity [11], anti-tumor [12], cytotoxic effects [6] and other activities [2]. Previous antioxidative studies conducted on oligomers of vitisinols B, C, D; $(+)$ - $\varepsilon$-viniferin, (-)-viniferal, ampelopsin $\mathrm{C}$ and $(+)$-vitisin $\mathrm{C}$ from the roots of Vitis thunbergii (Vitaceae) have shown that they have strong free RSA with $\mathrm{IC}_{50}$ values between 2.8 and $6.6 \mu \mathrm{M}$ [1]. New resveratrol trimers and tetramer of wilsonols $\mathrm{A}, \mathrm{B}, \mathrm{C}$ and diviniferin $\mathrm{B}$ from $\mathrm{V}$. wilsonae also exhibited potent antioxidant activities towards $\mathrm{DPPH}$ with $\mathrm{IC}_{50}$ values of 103.5, 195.4, 182.2 and $175.3 \mu \mathrm{M}$ respectively [13]. Structure-activity relationship studies revealed that the DPPH RSA of resveratrol dimers isolated from Cyperus longus (Cyperaceae) of longusols A, B, C; longusone A and trans-scirpusins $\mathrm{A}, \mathrm{B}$ was stronger $\left(\mathrm{IC}_{50} \mathrm{~S} 2.8\right.$ to $\left.9.3 \mu \mathrm{M}\right)$ than those of the monomers piceatanol and resveratrol ( $\mathrm{IC}_{50} \mathrm{~s} 11$ and $24 \mu \mathrm{M}$, respectively) [5]. The DPPH RSA study previously conducted on resveratrol oligomers isolated from Parthenocissus laetevirens (Vitaceae) of laetevirenols A and B containing an unusual phenanthrene moiety which exhibited much stronger antioxidant activities (38.4 and $37.3 \mu \mathrm{M})$ compared to those without that moiety of laetevirenols C-E $(110.8,128.0$ and $158.2 \mu \mathrm{M})$ [7]. An unusual resveratrol hexamer of chunganenol isolated from $V$. chunganensis, which was composed of more than five monomers, exhibited much stronger DPPH RSA than two resveratrol trimers from the same species of $(+)$-gnetin $\mathrm{H}$ and $(+)$-amurensin $\mathrm{G}$ (with respective values of 37.3; 251.0 and $138.0 \mu \mathrm{M})[8]$.

Shorea is the largest genus in the Dipterocarpaceae family. To date, about 26 resveratrol oligomers have been successfully isolated from this genus [1]. Shorea acuminata Dyer is a timber tree which is classified as light Red Meranti and locally known as Meranti Rambai Daun. The distribution of the species ranges from the Malay Peninsula to Sumatra and up to the Lingga Archipelago. It occurs on low-lying and well-drained land, but it is more abundant in hilly areas up to $300 \mathrm{~m} \mathrm{[14].}$ A previous phytochemical study on Shorea acuminata resin had resulted in the characterization of $2 \alpha, 3 \alpha$-dihydroxyolean-12-en-28-oic, mangiferonic, $2 \alpha$-hydroxyursolic and asiatic acids [15]. In our ongoing search for resveratrol oligomers, we now report the isolation and structural elucidation of a new resveratrol oligomer derivative named acuminatol (1) and the five known compounds laevifonol (2) [16], (+)- $\alpha$-viniferin (3) [17], shoreaketone (4) [18], vaticanol B (5) [19] and (-)-hopeaphenol (6) [20] (Figure 1). This is the first phytochemical report on resveratrol oligomers isolated from S. acuminata that incorporates their antioxidant activity against DPPH radical and BCLA, and also their cytotoxic property against Vero cells. 
Figure 1. Structures of $\mathbf{1 - 6 .}$

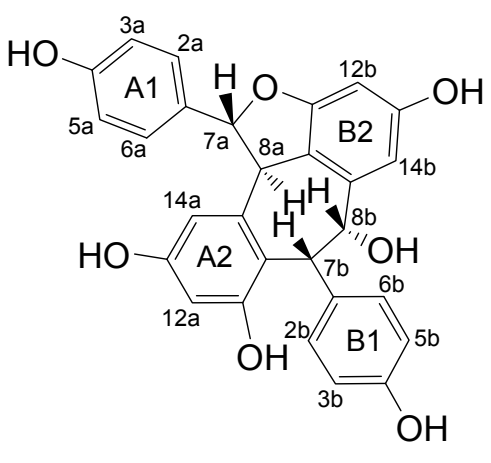

1
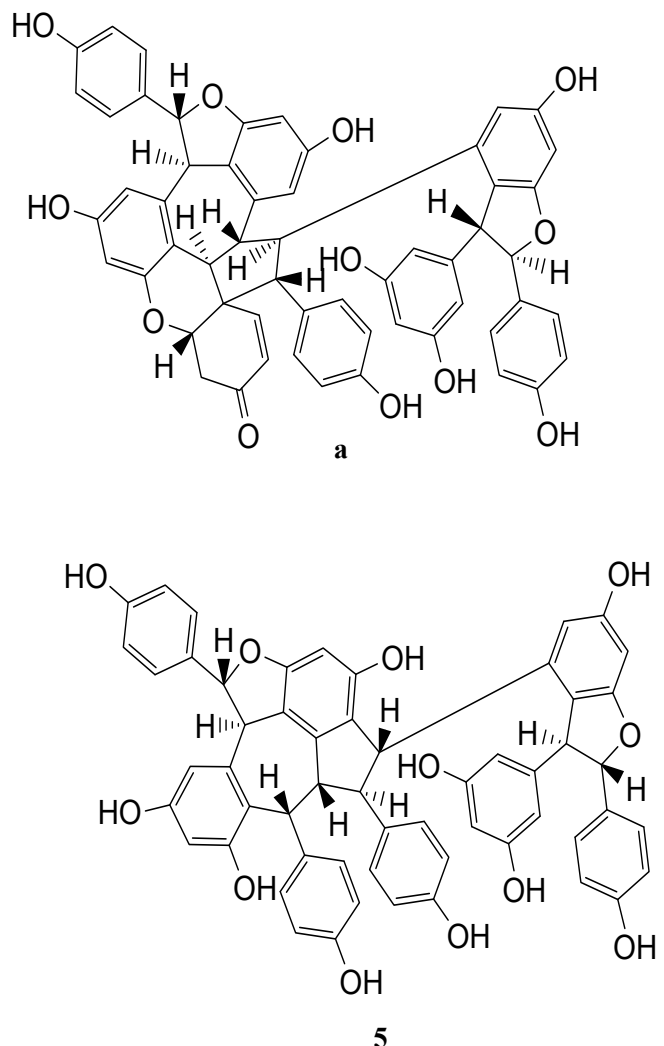

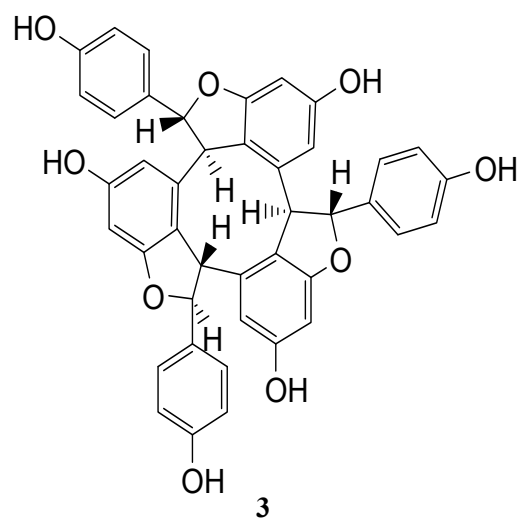

2

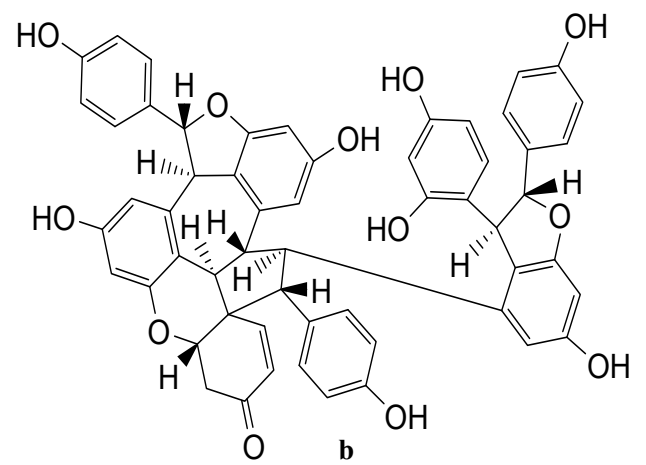

4

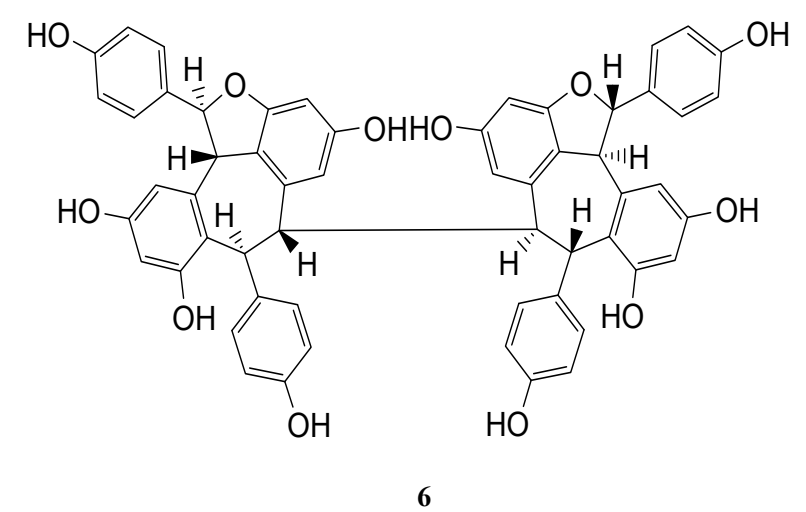

\section{Results and Discussion}

\subsection{Structure Elucidation}

Compound 1 was isolated as a yellow amorphous solid, mp $186-188^{\circ} \mathrm{C},[\alpha]_{\mathrm{D}}^{19}-42^{\circ}$ (c 0.00024 , $\mathrm{MeOH}$ ), which exhibited a molecular ion peak in the negative-ion high resolution ESIMS at $[\mathrm{M}-\mathrm{H}]^{-}$ $m / z 469.1275$ (calcd. 469.1293) attributable to the molecular formula $\mathrm{C}_{28} \mathrm{H}_{22} \mathrm{O}_{7}$, which corresponded to a resveratrol dimer. This assumption was reinforced by the UV and IR absorption data, together with the ${ }^{1} \mathrm{H}$ - and ${ }^{13} \mathrm{C}$-APT NMR data, which was assigned by the interpretation of the HMQC, HMBC, ${ }^{1} \mathrm{H}-{ }^{1} \mathrm{H}$ COSY and NOESY spectra (Table 1). UV absorption $\lambda_{\max } \mathrm{nm}(\mathrm{MeOH}): 282$; IR $(\mathrm{KBr})$ $v_{\max } \mathrm{cm}^{-1}: 3366(\mathrm{OH}), 2922(\mathrm{C}-\mathrm{H}$ aliphatic), 1602, 1516 and $1449(\mathrm{C}=\mathrm{C}$ aromatic), 1249 and 1175 (C-O oxyaryl), and 835 ( $p$-disubstituted benzene). 
Table 1. ${ }^{13} \mathrm{C}$ - and ${ }^{1} \mathrm{H}-\mathrm{NMR}$ spectral data * of $\mathbf{1}$.

\begin{tabular}{|c|c|c|c|c|c|}
\hline Position & $\boldsymbol{\delta}_{\mathrm{C}}$ & $\delta_{\mathrm{H}}$ mult. $(J$ in $\mathrm{Hz})$ & ${ }^{13} \mathrm{C}-{ }^{1} \mathrm{H}$ HMBC & ${ }^{1} \mathrm{H}-{ }^{1} \mathrm{H} \mathrm{COSY}$ & ${ }^{1} \mathrm{H}-{ }^{1} \mathrm{H}$ NOESY \\
\hline $1 \mathrm{a}$ & 129.9 & - & $3 a(5 a), 8 a$ & - & \\
\hline $2 \mathrm{a} / 6 \mathrm{a}$ & 129.3 & $7.09 \mathrm{~d}(8.6)$ & $7 \mathrm{a}$ & $3 a(5 a)$ & $8 a, 14 a, 7 a, 3 a(5 a)$ \\
\hline $3 \mathrm{a} / 5 \mathrm{a}$ & 115.2 & $6.76 \mathrm{~d}(8.6)$ & $\mathrm{OH}_{4 \mathrm{a}}$ & $2 \mathrm{a}(6 \mathrm{a})$ & $2 \mathrm{a}(6 \mathrm{a}), \mathrm{OH}_{4 \mathrm{a}}$ \\
\hline $4 a$ & 158.9 & - & $3 \mathrm{a}(5 \mathrm{a}), \mathrm{OH}_{4 \mathrm{a}}$ & - & - \\
\hline $7 a$ & 87.5 & $5.67 \mathrm{~d}(11.7)$ & $2 \mathrm{a}(6 \mathrm{a}), 8 \mathrm{a}$ & $8 \mathrm{a}$ & $8 \mathrm{a}, 14 \mathrm{a}, 2 \mathrm{a}(6 \mathrm{a})$ \\
\hline $8 \mathrm{a}$ & 49.1 & $4.19 \mathrm{~d}(11.7)$ & $7 \mathrm{a}, 14 \mathrm{a}$ & $7 \mathrm{a}$ & $7 \mathrm{a}, 2 \mathrm{a}(6 \mathrm{a}), 2 \mathrm{~b}(6 \mathrm{~b})$ \\
\hline $9 \mathrm{a}$ & 141.3 & - & $7 \mathrm{a}, 8 \mathrm{a}, 8 \mathrm{~b}$ & - & - \\
\hline $10 \mathrm{a}$ & 120.3 & - & $7 \mathrm{~b}, 14 \mathrm{a}, 12 \mathrm{a}, \mathrm{OH}_{11 \mathrm{a}}$ & - & - \\
\hline $11 \mathrm{a}$ & 156.5 & - & $7 \mathrm{~b}, 12 \mathrm{a}, \mathrm{OH}_{11 \mathrm{a}}$ & - & - \\
\hline $12 \mathrm{a}$ & 100.5 & $6.41 \mathrm{~d}(1.5)$ & $14 \mathrm{a}, \mathrm{OH}_{13 \mathrm{a}}$ & $14 \mathrm{a}$ & $14 \mathrm{a}, \mathrm{OH}_{11 \mathrm{a}}$ \\
\hline $13 \mathrm{a}$ & 157.7 & - & $\mathrm{OH}_{13 \mathrm{a}}$ & - & - \\
\hline $14 \mathrm{a}$ & 104.6 & $6.18 \mathrm{br} \mathrm{s}$ & $\mathrm{OH}_{13 \mathrm{a}}$ & $12 \mathrm{a}$ & $7 \mathrm{a}, 12 \mathrm{a}, 2 \mathrm{a}(6 \mathrm{a}), \mathrm{OH}_{13 \mathrm{a}}$ \\
\hline $1 b$ & 131.9 & - & $7 b, 3 b(5 b)$ & - & - \\
\hline $2 \mathrm{~b} / 6 \mathrm{~b}$ & 129.1 & $7.13 \mathrm{~d}(8.2)$ & $2 b(6 b)$ & $3 \mathrm{~b} / 5 \mathrm{~b}$ & $7 b, 3 b(5 b), 8 a$ \\
\hline $3 \mathrm{~b} / 5 \mathrm{~b}$ & 114.2 & $6.57 \mathrm{~d}(8.2)$ & $\mathrm{OH}_{4 \mathrm{~b}}$ & $2 b(6 b)$ & $2 b(6 b)$ \\
\hline $4 b$ & 155.0 & - & $2 \mathrm{~b}(6 \mathrm{~b}), \mathrm{OH}_{4 \mathrm{~b}}$ & - & - \\
\hline $7 \mathrm{~b}$ & 45.0 & $5.46 \mathrm{br} \mathrm{s}$ & - & $8 b$ & $8 b, 2 b(6 b)$ \\
\hline $8 b$ & 71.0 & $5.09 \mathrm{br} \mathrm{s}$ & $7 b, 14 b, 9 a$ & $7 b$ & $7 b, 14 b$ \\
\hline $9 b$ & 141.6 & - & $7 b, 8 a$ & - & - \\
\hline $10 \mathrm{~b}$ & 116.7 & - & $8 \mathrm{a}, 12 \mathrm{~b}, 14 \mathrm{~b}$ & - & - \\
\hline $11 b$ & 158.1 & - & - & - & - \\
\hline $12 \mathrm{~b}$ & 95.4 & $6.11 \mathrm{~d}(1.8)$ & $14 \mathrm{~b}, \mathrm{OH}_{13 \mathrm{~b}}$ & $14 b$ & $14 \mathrm{~b}, \mathrm{OH}_{13 \mathrm{~b}}$ \\
\hline $13 b$ & 156.0 & - & - & - & - \\
\hline $14 b$ & 106.4 & $6.94 \mathrm{~d}(1.8)$ & $\mathrm{OH}_{13 \mathrm{~b}}$ & $12 \mathrm{~b}$ & $8 b, 12 b, O H_{13 b}$ \\
\hline $\mathrm{OH}_{8 \mathrm{~b}}$ & - & 3.63 & & - & \\
\hline $\mathrm{OH}_{11 \mathrm{a}}$ & - & 8.57 & & - & \\
\hline $\mathrm{OH}_{4 \mathrm{a}}$ & - & 8.54 & & - & \\
\hline $\mathrm{OH}_{13 \mathrm{~b}}$ & - & 8.23 & & - & \\
\hline $\mathrm{OH}_{13 \mathrm{a}}$ & - & 8.22 & & - & \\
\hline $\mathrm{OH}_{4 \mathrm{~b}}$ & - & 8.05 & & - & \\
\hline
\end{tabular}

The ${ }^{1} \mathrm{H}-\mathrm{NMR}$ spectral data of $\mathbf{1}$ exhibited the presence of two sets of ortho-coupled aromatic protons which can be assigned to two 4-hydroxyphenyl groups [ring A1: $\delta 7.09(2 \mathrm{H}, \mathrm{d}, J=8.6 \mathrm{~Hz}$, $\mathrm{H}-2 \mathrm{a}$ and $6 \mathrm{a}), \delta 6.76(2 \mathrm{H}, \mathrm{d}, J=8.6 \mathrm{~Hz}, \mathrm{H}-3 \mathrm{a}$ and $5 \mathrm{a})$, and $\operatorname{ring} \mathrm{B} 1: \delta 7.13(2 \mathrm{H}, \mathrm{d}, J=8.2 \mathrm{~Hz}, \mathrm{H}-2 \mathrm{~b}$ and $6 \mathrm{~b}), \delta 6.57(2 \mathrm{H}, \mathrm{d}, J=8.2 \mathrm{~Hz}, \mathrm{H}-3 \mathrm{~b}$ and $5 \mathrm{~b})]$, two sets of meta-coupled aromatic protons on two 1,2,3,5-tetrasubstituted benzene rings [ring A2: $\delta 6.18(1 \mathrm{H}$, br s, H-14a), $\delta 6.41(1 \mathrm{H}, \mathrm{d}, J=1.5 \mathrm{~Hz}$, $\mathrm{H}-12 \mathrm{a})$, and ring B2: $\delta 6.94(1 \mathrm{H}, \mathrm{d}, J=1.8 \mathrm{~Hz}, \mathrm{H}-14 \mathrm{~b}), \delta 6.11(1 \mathrm{H}, \mathrm{d}, J=1.8 \mathrm{~Hz}, \mathrm{H}-12 \mathrm{~b})]$, five phenolic hydroxyl groups $(\delta 8.05,8.22,8.23,8.54$ and 8.57$)$, and one aliphatic hydroxyl group ( $\delta$ 3.63). The ${ }^{1} \mathrm{H}-\mathrm{NMR}$ spectrum also showed two pairs of aliphatic methine protons coupled successively: $\mathrm{H}-7 \mathrm{a}(\delta 5.67, \mathrm{~d}, J=11.7)$ and $\mathrm{H}-8 \mathrm{a}(\delta 4.19, \mathrm{~d}, J=11.7)$; H-7b $(\delta 5.46$, br s) and $\mathrm{H}-8 \mathrm{~b}$ ( $\delta 5.09$, br s) as shown in Table 2. The large coupling constant of H-7a and H-8a $(11.7 \mathrm{~Hz})$ in compound 1 indicated that the protons were in trans orientation [21], which is also exhibited by its 
stereoisomers, namely (+)-ampelopsin A $(11.7 \mathrm{~Hz})$ [22], (-)-hemsleyanol A $(9.8 \mathrm{~Hz})$ [17] and (+)-balanocarpol $(9.3 \mathrm{~Hz})$ [23]. On the other hand, $\mathrm{H}-7 \mathrm{~b}$ and $\mathrm{H}-8 \mathrm{~b}$ of $\mathbf{1}$ gave two broad singlets as those in (+)-balanocarpol [23], which proved that the two protons were in cis orientation. However, trans $-\mathrm{H}-7 \mathrm{~b} \sim \mathrm{H}-8 \mathrm{~b}$ in (+)-ampelopsin $\mathrm{A}$ [22] and (-)-hemsleyanol A [17] gave coupling constants of 5.0 and $5.9 \mathrm{~Hz}$ for $\mathrm{H}-7 \mathrm{~b}$ whereas $\mathrm{H}-8 \mathrm{~b}$ produced broad singlet and broad doublet respectively.

Table 2. Chemical shifts of aliphatic proton pairs of $\mathrm{H}-7 \mathrm{a} \sim \mathrm{H}-8 \mathrm{a}$ and $\mathrm{H}-7 \mathrm{~b} \sim \mathrm{H}-8 \mathrm{~b}$ for stereoisomers 1, (+)-ampelopsin A [22], (-)-hemsleyanol A [17] and (+)-balanocarpol [23].

\begin{tabular}{lllll}
\hline \multirow{2}{*}{ Compound } & \multicolumn{4}{c}{$\boldsymbol{\delta}_{\mathbf{H}}$ mult. $(\boldsymbol{J}$ in $\mathbf{H z})$} \\
\cline { 2 - 5 } & $\mathbf{7 a}$ & $\mathbf{8 a}$ & $\mathbf{7 b}$ & $\mathbf{8 b}$ \\
\hline $\mathbf{1}^{\text {a }}$ & $\beta: 5.67(\mathrm{~d}, 11.7)$ & $\alpha: 4.19(\mathrm{~d}, 11.7)$ & $\beta: 5.46(\mathrm{br} \mathrm{s})$ & $\beta: 5.09(\mathrm{br} \mathrm{s})$ \\
(+)-Ampelopsin A $^{\mathrm{b}}$ & $\alpha: 5.77(\mathrm{~d}, 11.7)$ & $\beta: 4.17(\mathrm{brd}, 11.7)$ & $\alpha: 5.45(\mathrm{~d}, 5.0)$ & $\beta: 5.42(\mathrm{br} \mathrm{s})$ \\
$\left(_{(-)_{\text {-Hemsleyanol A }}}{ }^{\mathrm{a}}\right.$ & $\beta: 5.75(\mathrm{~d}, 9.8)$ & $\alpha: 5.41(\mathrm{~d}, 9.8)$ & $\alpha: 5.07(\mathrm{~d}, 5.9)$ & $\beta: 4.76(\mathrm{brd})$ \\
(+)-Balanocarpol $^{\mathrm{a}}$ & $\beta: 5.69(\mathrm{~d}, 9.3)$ & $\alpha: 5.16(\mathrm{brd}, 9.3)$ & $\alpha: 4.90(\mathrm{br} \mathrm{s})$ & $\alpha: 5.40(\mathrm{br} \mathrm{s})$ \\
\hline
\end{tabular}

${ }^{\mathrm{a}}$ Measured in acetone- $d_{6}(400 \mathrm{MHz}) ;{ }^{\mathrm{b}}$ measured in acetone- $d_{6}(500 \mathrm{MHz})$.

Relative configuration of methine protons at $\mathrm{C}-8 \mathrm{a}, \mathrm{C}-7 \mathrm{~b}$ and $\mathrm{C}-8 \mathrm{~b}$ on a cycloheptane ring in compound 1 can be further verified by the results of NOESY experiment. The absence of NOEs between $\mathrm{H}-8 \mathrm{a}$ and either $\mathrm{H}-7 \mathrm{~b}$ or $\mathrm{H}-8 \mathrm{~b}$ revealed that $\mathrm{H}-8 \mathrm{a}$ and $\mathrm{H}-7 \mathrm{~b} \sim \mathrm{H}-8 \mathrm{~b}$ were in opposite sides of the cycloheptane ring. This also confirmed that both $\mathrm{H}-7 \mathrm{~b}$ and $\mathrm{H}-8 \mathrm{~b}$ were in the cis position. $(+)$-Balanocarpol where all three hydrogens were on the same side of the cycloheptane ring had significant NOEs between $\mathrm{H}-8 \mathrm{a} / \mathrm{H}-7 \mathrm{~b}$ and $\mathrm{H}-8 \mathrm{a} / \mathrm{H}-8 \mathrm{~b}$ [23]. Since $\mathrm{H}-7 \mathrm{a}$ and $\mathrm{H}-8 \mathrm{a}$ of 1 were trans based on the above ${ }^{1} \mathrm{H}-\mathrm{NMR}$ spectral data, the relative configuration of methine protons at $\mathrm{C}-7 \mathrm{a}, \mathrm{C}-8 \mathrm{a}, \mathrm{C}-7 \mathrm{~b}$ and $\mathrm{C}-8 \mathrm{~b}$ were $\beta, \alpha, \beta$ and $\beta$. Other significant NOEs in support of these observations were between $\beta$ $\mathrm{H}-7 \mathrm{a} / \mathrm{H}-14 \mathrm{a}, \beta \mathrm{H}-7 \mathrm{~b} / \beta \mathrm{H}-8 \mathrm{~b}$ and $\beta \mathrm{H}-8 \mathrm{~b} / \mathrm{H}-14 \mathrm{~b}$. In the HMBC spectrum (Table 1, Figure 2a), significant correlations were observed between C-2a(6a)/H-7a, C-8a/H-7a, C-9a/H-7a, C-9a/H-8a and $\mathrm{C}-10 \mathrm{~b} / \mathrm{H}-8 \mathrm{a}$, indicated that a pair of benzylic methine protons of $\beta \mathrm{H}-7 \mathrm{a}$ and $\alpha \mathrm{H}-8 \mathrm{a}$ was assigned to the protons on a dihydrofuran ring.

Figure 2. Key HMBC (a) and NOE (b) correlations for $\mathbf{1 .}$

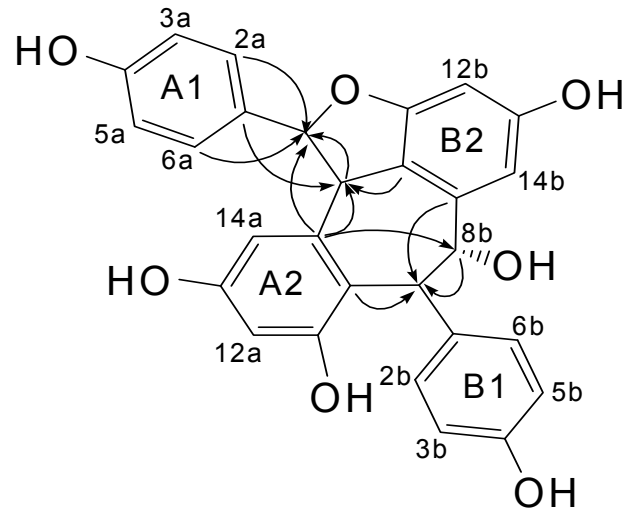

(a)

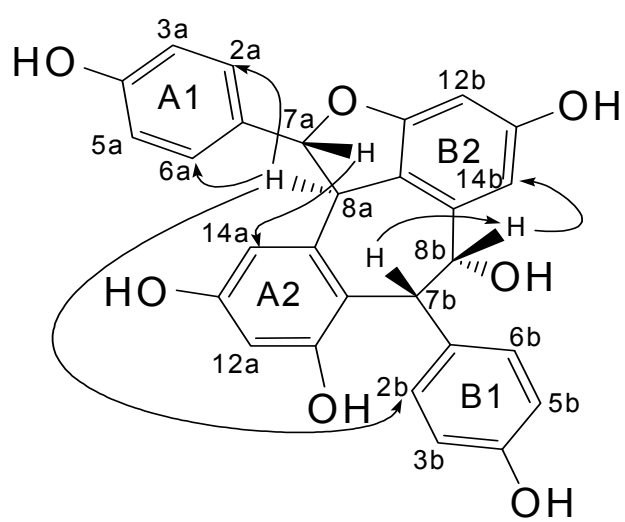

(b)

There were significant correlations observed between C-9a/H-8b, C-9b/H-7b, C-1b/H-7b, C-11a/H-7b, $\mathrm{C}-10 \mathrm{a} / \mathrm{H}-7 \mathrm{~b}$ and $\mathrm{C}-8 \mathrm{~b} / \mathrm{H}-7 \mathrm{~b}$. These correlations proved that there was one more pair of methine protons 
attached to $\mathrm{C}-7 \mathrm{~b}(\beta \mathrm{H}-7 \mathrm{~b})$ and $\mathrm{C}-8 \mathrm{~b}(\beta \mathrm{H}-8 \mathrm{~b})$. The relative stereo structure for compound 1 was confirmed as shown in Figure 1. It should be noted that the above three resveratrol dimers, which were stereoisomers to compound 1, were previously isolated from Ampelopsis brevipedunculata var. hancei (Vitaceae) [(+)-ampelopsin A] [22], H. parvifolia (Dipterocarpaceae) [(+)-balanocarpol] [23] and Shorea hemsleyana (Dipterocarpaceae) [(-)-hemsleyanol A] [17].

All of the four stereoisomers shared a same basic planar structure. However, the chemical shifts for aliphatic protons of $\mathrm{H}-7 \mathrm{a}, \mathrm{H}-8 \mathrm{a}, \mathrm{H}-7 \mathrm{~b}$ and $\mathrm{H}-8 \mathrm{~b}$ of the four stereoisomers were markedly different as shown in Table 2. These differences have been suggested to be mainly due to the A1 and B1 rings in their energy-optimized conformations as in Figure 3.

Figure 3. Energy-optimized stereo structures of 1 (a), (+)-ampelopsin A (b), $(-)$-hemsleyanol A (c) and (+)-balanocarpol (d).

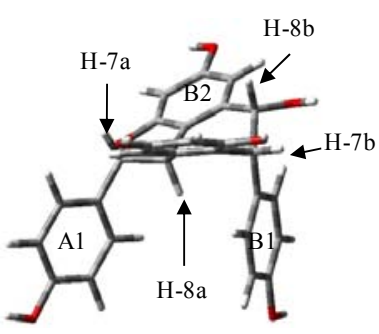

a (cis)

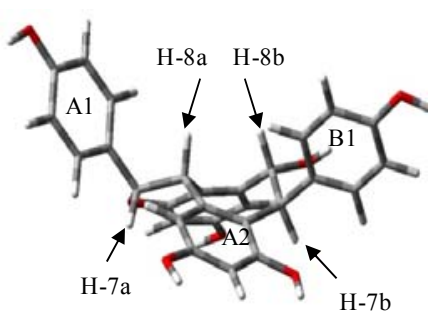

b (skew-cis)

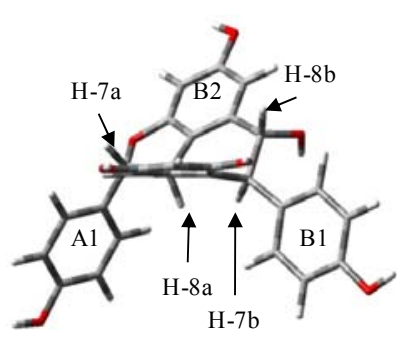

c (skew-cis)

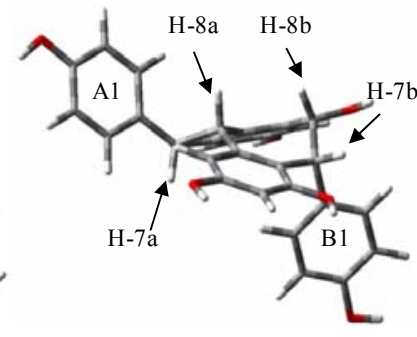

$\mathrm{d}($ trans $)$

The NOE interactions between $\mathrm{H}-8 \mathrm{a} / \mathrm{H}-2 \mathrm{a}(6 \mathrm{a}), \mathrm{H}-7 \mathrm{a} / \mathrm{H}-14 \mathrm{a}, \mathrm{H}-8 \mathrm{~b} / \mathrm{H}-14 \mathrm{~b}$ and $\mathrm{H}-8 \mathrm{a} / \mathrm{H}-2 \mathrm{~b}(6 \mathrm{~b})$ in compound 1 (Figure 3a) and (+)-ampelopsin A (Figure 3b) [22] lead to cis and skew-cis conformations, while the absence of NOE interaction between $\mathrm{H}-8 \mathrm{a} / \mathrm{H}-2 \mathrm{~b}(6 \mathrm{~b})$ in $(+)$-balanocarpol (Figure 3d) [23] would suggest that it was in a trans conformation. The absence of NOE interaction between $\mathrm{H}-8 \mathrm{a} / \mathrm{H}-2 \mathrm{~b}(6 \mathrm{~b})$ in the skew-cis conformation of (-)-hemsleyanol A (Figure 3c) [17], unlike that in the skew-cis conformation of (+)-ampelopsin A, was due to the relative positions of $\mathrm{H}-8 \mathrm{a}$ and B1 ring which were farther apart in the actual energy-optimized 3D-model of the molecule. It should be noted that the NOE correlations between $\mathrm{H}-2 \mathrm{a}(6 \mathrm{a}) / \mathrm{H}-14 \mathrm{a}$ and $\mathrm{H}-7 \mathrm{a} / \mathrm{H}-8 \mathrm{a}$ in compound 1 seem to suggest that the $\mathrm{H}-7 \mathrm{a}$ and $\mathrm{H}-8 \mathrm{a}$ were cis to each other with $\mathrm{H}-7 \mathrm{a}$ in $\alpha$ position. However, this contradicted with the large coupling constants between $\mathrm{H}-7 \mathrm{a}$ and $\mathrm{H}-8 \mathrm{a}$ of the trans in compound 1 $(11.7 \mathrm{~Hz})$ as well as in its stereoisomers of (+)-ampelopsin A (11.7 Hz) [22], (-)-hemsleyanol A $(9.8 \mathrm{~Hz})$ [17] and (+)-balanocarpol $(9.3 \mathrm{~Hz})$ [23]. The chemical shift for $\mathrm{H}-8 \mathrm{a}$ in compound 1 was more upfield $(\delta 4.19)$ like the one found in (+)-ampelopsin A $(\delta 4.17)$ [22] when compared to that in $(-)$-hemsleyanol A $(\delta$ 5.41) [17] and (+)-balanocarpol ( $\delta$ 5.16) [23]. This strongly suggested that the $\mathrm{A} 1$ and $\mathrm{B} 1$ rings in compound $\mathbf{1}$ and $(+)$-ampelopsin A were in cis configuration. The chemical shifts for $\mathrm{H}-8 \mathrm{a}$ in (-)-hemsleyanol $\mathrm{A}$ and $(+)$-balanocarpol which appeared 1.23 and $0.98 \mathrm{ppm}$ more downfield indicated that the $\mathrm{A} 1$ and $\mathrm{B} 1$ rings for the latter were in trans configuration (Table 2). Although the $\mathrm{A} 1$ and $\mathrm{B} 1$ rings for (-)-hemsleyanol A were in cis configuration, its B1 ring did not give any deshielding effect like in (+)-balanocarpol since those rings were in the same orientation as shown in Figure 3c,d. The $\mathrm{H}-8 \mathrm{a}$ in $(-)$-hemsleyanol $\mathrm{A}$ was more deshielded than that in (+)-balanocarpol because the former lay within the deshielding area up front to the A1 ring whereas this ring in the latter was a little tilted. Moreover NOE correlations [Table 1, Figure 2b] between $\mathrm{H}-8 \mathrm{a} / \mathrm{H}-2 \mathrm{a}(6 \mathrm{a})$ and 
$\mathrm{H}-8 \mathrm{a} / \mathrm{H}-2 \mathrm{~b}(6 \mathrm{~b})$ in compound 1 positively suggested that its $\mathrm{A} 1, \mathrm{H}-8 \mathrm{a}$ and $\mathrm{B} 1$ were all on the same side of the plane. The results from the energy-optimized conformations as calculated by GaussView 5.0 and Gaussian 09W using DFT-6-31G-(d,p) method, have confirmed the above deductions (Figure 3). Therefore, $\mathbf{1}$ is a new stereoisomer of these three compounds.

\subsection{Antioxidant Activity}

\subsubsection{DPPH Assay}

As shown in Table 3, the scavenging activity of compounds $\mathbf{1}$ to $\mathbf{6}$ towards DPPH free radicals was expressed in terms of $\mathrm{IC}_{50}$ values. Since lower $\mathrm{IC}_{50}$ values indicated stronger ability of the compounds to act as DPPH radical scavengers, it was obvious that the positive controls were excellent DPPH radical scavengers with AscA and BHT exhibited average 6- and 4-fold higher scavenging activities $\left(\mathrm{IC}_{50}=0.68\right.$ and $0.95 \mathrm{mM}$, respectively) compared to compounds 1 to $6\left(\mathrm{IC}_{50} \mathrm{~S}=0.84\right.$ to $\left.10.06 \mathrm{mM}\right)$. Compound 5 exhibited excellent $\mathrm{RSA}$ with $\mathrm{IC}_{50}$ having no significant difference $(p>0.05)$ compared to positive controls of AscA and BHT. The antioxidant activitiy of all compounds and positive controls was in the following order (Table 3): AscA $\sim \mathbf{5} \sim$ BHT $>\mathbf{4}>\mathbf{6}>\mathbf{2}>\mathbf{3}>\mathbf{1}$.

Table 3. Antioxidant and cytotoxic activities of compounds $\mathbf{1}$ to $\mathbf{6}$.

\begin{tabular}{cccc}
\hline Compound & $\begin{array}{c}\text { DPPH radical scavenging } \\
\text { activities }\left(\mathbf{I C}_{\mathbf{5 0}}, \mathbf{m M}\right)\end{array}$ & $\begin{array}{c}\text { BCLA method } \\
\left.\mathbf{I C}_{\mathbf{5 0}}, \mathbf{m M} \mathbf{m}\right)\end{array}$ & $\begin{array}{c}\text { Cytotoxic activities on Vero } \\
\text { cell lines }\left(\mathbf{L C}_{\mathbf{5 0}}, \boldsymbol{\mu M} \mathbf{M}\right)\end{array}$ \\
\hline $\mathbf{1}$ & $10.06 \pm 0.05^{\mathrm{f}}$ & $0.18 \pm 0.01^{\mathrm{a}}$ & 400 \\
$\mathbf{2}$ & $4.21 \pm 0.23^{\mathrm{d}}$ & $0.22 \pm 0.02^{\mathrm{a}}$ & 597 \\
$\mathbf{3}$ & $6.29 \pm 0.05^{\mathrm{e}}$ & $0.18 \pm 0.00^{\mathrm{a}}$ & 208 \\
$\mathbf{4}$ & $1.54 \pm 0.10^{\mathrm{b}}$ & $0.11 \pm 0.00^{\mathrm{a}}$ & 830 \\
$\mathbf{5}$ & $0.84 \pm 0.02^{\mathrm{a}}$ & $0.10 \pm 0.01^{\mathrm{a}}$ & 759 \\
$\mathbf{6}$ & $2.78 \pm 0.16^{\mathrm{c}}$ & $0.10 \pm 0.01^{\mathrm{e}}$ & 161 \\
$\mathrm{AscA}^{\mathrm{z}}$ & $0.68 \pm 0.00^{\mathrm{a}}$ & $25.19 \pm 1.74^{\mathrm{b}}$ & - \\
$\mathrm{BHT}^{\mathrm{z}}$ & $0.95 \pm 0.05^{\mathrm{a}}$ & $0.09 \pm 0.00^{\mathrm{a}}$ & - \\
\hline
\end{tabular}

${ }^{\mathrm{a}-\mathrm{g}}$ Mean within each column with different letters differ significantly $(p<0.05)$. Each value is presented as mean $\pm \mathrm{SD}(n=3) .{ }^{\mathrm{z}}$ Positive reference standards; $\mathrm{IC}_{50}, 50 \%$ inhibition concentration.

These results, especially for the compounds 5, 4, 3 and 1 , were in agreement with the recent study on antioxidant activity which revealed that the RSA of the resveratrol oligomers was related to their structures. The multiple phenolic hydroxyl groups of 10, 8, 6 and 5 for the compounds 5, 4, 3 and 1 with four, three, three and two para-hydroxy groups, respectively, contributed to their being better hydrogen donors. Furthermore, the presence of the extensive double bond conjugation within the compounds which was responsible for electron delocalization has made them good as radical targets [3]. Compounds 6 and 2 with 10 and five aromatic-OHs, and four and two para-OHs of did not fit very well into the order. Other related studies by He et al. in 2009 [8] on eight stilbene oligomers from Vitis chunganensis (Vitaceae), that is, hexamer of chunganenol, tetramers of vitisin A and hopeaphenol (6), four trimers and one monomer revealed that chunganenol was the most active, as expected, followed by vitisin A, with hopeaphenol ranking fifth in the order. 


\subsubsection{BCLA Assay}

The antioxidant activity of the compounds $\mathbf{1}$ to $\mathbf{6}$ as well as the positive controls BHT and AscA, as measured by the bleaching of $\beta$-carotene, are presented in Table 3. It was noted that in this assay, AscA exhibited low antioxidant activity $\left(\mathrm{IC}_{50} 25.19 \mathrm{mM}\right)$ compared to BHT $\left(\mathrm{IC}_{50} 0.09 \mathrm{mM}\right)$ and compounds 1 to 6 ( $\mathrm{IC}_{50} 0.10$ to $\left.0.22 \mathrm{mM}\right)$. These results suggest that AscA is a weak antioxidant despite the fact that it is a well-known, polar antioxidant. Our results are in agreement with the previous report which pointed out that AscA did not show its antioxidant activity under similar assay [24]. In this assay, all compounds exhibited antioxidant activity with no significant difference $(p>0.05)$ than the positive control BHT. These results agree with previous report [1], which indicated that most stilbenoids possess antioxidant activity because they had polyphenol functions in the molecules.

\subsection{Cytotoxicity Assay}

The results of cytotoxicity evaluation of compounds $\mathbf{1}$ to $\mathbf{6}$ as $\mathrm{LC}_{50}(\mathrm{mM})$ are shown in Table 3 . The compounds were considered safe when their $\mathrm{LC}_{50} \mathrm{~S}$ are higher than $100 \mu \mathrm{M}$ [25]. All compounds tested possessed $\mathrm{LC}_{50}$ values more than $100 \mu \mathrm{M}(161$ to $830 \mu \mathrm{M})$.

\section{Experimental}

\subsection{General}

IR spectra were recorded on a Perkin Elmer GX FT-IR spectrophotometer (Waltham, MA, USA). UV spectra were measured on Shimadzu UV-160 (200-400 nm, Kyoto, Japan). ${ }^{1} \mathrm{H}$ and ${ }^{13} \mathrm{C}-\mathrm{APT}$ NMR spectra were recorded in acetone- $d_{6}$ using JEOL ECP400 spectrometer $\left(400\right.$ and $100 \mathrm{MHz}$ for ${ }^{1} \mathrm{H}$ and ${ }^{13} \mathrm{C}$; Akishima, Japan). Mass spectra were measured in electron spray ionization mode on Bruker (micro TOF-Q; Bremen, Germany) LC-MS spectrometer (ESI-MS in negative mode, Dionex, Sunnyvale, CA, USA). Melting points were determined by Stuart SMP10 melting point apparatus (Burlington, VT, USA) and were uncorrected. Optical rotations were recorded on Jasco Polarimeter P-1020 (Easton, MD, USA) in MeOH. Vacuum liquid chromatography (VLC) was carried out on Si-gel $60 \mathrm{GF}_{254}$ (Merck, Damstadt, Germany), radial chromatography (RC) was done on Si-gel 60 $\mathrm{PF}_{254}$ (Merck) and TLC was performed on pre-coated silica gel (Merck, Kieselgel $60 \mathrm{~F}_{254} 0.25 \mathrm{~mm}$ ), and detected by UV light $(254 \mathrm{~nm})$ or by $\mathrm{CeSO}_{4}$ spraying reagent followed by heating. All solvents used were of analytical grades. Absorbance values for BCLA and cytotoxic assays were measured on microplate reader (Labsystem Multiskan Multisoft, Basingstoke, UK) and DPPH assay on Shimadzu UVmini-1240 spectrophotometer (Kyoto, Japan). Dulbecco's Modified Eagle's Medium (DMEM) and fetal bovine serum (FBS) used to maintain and supplement the cell, respectively, were from Flowlab (North Ryde, Australia). Samples emulsifying was done on Branson 5200 (Los Angeles, CA, USA) sonicator. 


\subsection{Plant Material}

The stem bark of Shorea acuminata was collected from Universiti Kebangsaan Malaysia (UKM) Forest Reserve, Bangi, in September 2009. A voucher specimen (UKMB 23520) has been deposited in the UKM Herbarium, and identified by Mr. Sani Miran.

\subsection{Extraction and Isolation}

The dried powder of stem bark of Shorea acuminata $(1 \mathrm{~kg})$ was macerated with acetone $(3 \times 5 \mathrm{~L}$, 3 days each) at room temperature. The extract was concentrated using rotary evaporator to yield a brownish acetone extract $(49.6 \mathrm{~g}, 4.96 \%)$ that was fractionated by VLC eluted with mixtures of $n$-hexane-EtOAc of increasing polarity. The eluates that showed similar profile on TLC chromatogram were combined to give five fractions A-E. Fraction C $(1.5 \mathrm{~g})$ was subjected to $\mathrm{RC}$ by eluting with $\mathrm{CHCl}_{3}-\mathrm{MeOH}(9: 1)$ to afford compound 3 (4.9 mg). Purification of fraction D (400 $\mathrm{mg}$ ) by RC using $\mathrm{CHCl}_{3}-\mathrm{MeOH}$ (8.4:1.6) followed by preparative TLC $\left(\mathrm{CHCl}_{3}-\mathrm{MeOH}, 8.2: 1.8\right)$ gave compounds 1 (12.0 mg), 2 (4.0 mg) and 4 (7.6 mg). Purification of fraction E (600 mg) by RC using $\mathrm{CHCl}_{3}-\mathrm{MeOH}$ (8:2) followed by preparative TLC afforded compounds $5(22.5 \mathrm{mg})$ and $\mathbf{6}(5.2 \mathrm{mg})$.

Compound 1: Yellow amorphous solid, m.p. $186-188{ }^{\circ} \mathrm{C},[\alpha]_{\mathrm{D}}^{19}-42^{\circ}$ (c $\left.0.00024, \mathrm{MeOH}\right), \mathrm{UV}$ $(\mathrm{MeOH}) \lambda_{\max } 282 \mathrm{~nm}$; IR (KBr) $v_{\max } \mathrm{cm}^{-1}$ : 3366, 2922, 1602, 1516 and 1449, 1249 and 1175, 835. ESIMS (neg): $m / z 469.1275$ [M-H] $]^{-}$, calcd: $469.1293 ;{ }^{1} \mathrm{H}-$ and ${ }^{13} \mathrm{C}-\mathrm{NMR}$ data, see Table 1.

\subsection{Antioxidant Assays}

\subsubsection{DPPH Assay}

The antioxidant activity of all six compounds was determined by the DPPH radical scavenging method according to the previous procedure [26] with modification. Each compound was diluted two-fold in a series of five starting from $5.00 \mathrm{mg} / \mathrm{mL}$. The solution of DPPH in methanol $\left(6 \times 10^{-5} \mathrm{M}\right)$ was prepared daily before UV measurements. A $3 \mathrm{~mL}$ aliquot of this solution was mixed with $77 \mu \mathrm{L}$ of the compound solution in a $1-\mathrm{cm}$ path length microcuvette. The mixture was shaken vigorously. The mixtures were then kept in the dark for $15 \mathrm{~min}$ at room temperature and the decrease in absorption was measured immediately in a UV-Vis spectrophotometer at $515 \mathrm{~nm}$. The blank solution containing the same amount of methanol and DPPH solution was prepared and its absorption was measured daily. The experiment was carried out in triplicate. AscA and BHT were used as positive controls. The RSA of samples, expressed as percentage inhibition of DPPH, was calculated according to the formula: Inhibition percentage $(I p)=\left[\left(A_{B}-A_{A}\right) / A_{B}\right] \times 100$, where $A_{B}$ and $A_{A}$ are the absorbance valueschecked after $15 \mathrm{~min}$ - of the blank sample and of the tested sample solutions, respectively. The $\mathrm{IC}_{50}$ values, which represented the concentrations of the tested samples and standards that caused 50\% RSA of DPPH, were calculated from the plots of inhibition percentages against concentrations. 


\subsubsection{BCLA Assay}

This test was carried out according to the reported method of literature [27] with modification. Approximately $4 \mathrm{~mL}$ of a solution of $\beta$-carotene in chloroform $(1 \mathrm{mg} / \mathrm{mL})$ were pipetted into a flask containing $40 \mathrm{mg}$ of linoleic acid and $400 \mathrm{mg}$ of Tween-40. The chloroform was removed using a rotary evaporator at $40{ }^{\circ} \mathrm{C}$ for $5 \mathrm{~min}$, and to the residue, $100 \mathrm{~mL}$ of distilled water were added, slowly with vigorous agitation, to form an emulsion. A 96-well micro-titer plate was added with $50 \mu \mathrm{L}$ of the Part 2.4.1 solution of the test compound and $200 \mu \mathrm{L}$ of the emulsion, and the absorbance was measured at $450 \mathrm{~nm}$, immediately, against a blank consisting of the emulsion without $\beta$-carotene. The plate was allowed to stand at room temperature $\left(20-23{ }^{\circ} \mathrm{C}\right)$, and the absorbance measurements were conducted again at $30 \mathrm{~min}$ intervals up to $120 \mathrm{~min}$. All tests were carried out in triplicate. Stable antioxidants of AscA and BHT were used as positive controls. The antioxidant activity (AA) of the test samples was evaluated in terms of bleaching of $\beta$-carotene using the formula; $A A=\left[1-\left(A_{0}-A_{t}\right) /\right.$ $\left.\left(A_{0}{ }^{\prime}-A_{t}{ }^{\prime}\right)\right] \times 100$, where $A_{0}$ and $A_{0}^{\prime}$ are the absorbance values measured at zero time of the sample and the blank, respectively, and $A_{t}$ and $A_{t}{ }^{\prime}$ are the absorbance measured in the test sample and the blank, respectively, at times up to $120 \mathrm{~min}$. The $\mathrm{IC}_{50}$ values, which represented the concentrations of the tested samples and standards that caused 50\% bleaching of BCLA, were calculated from the plots of inhibition percentages against concentrations.

\subsection{Cytotoxicity Assay}

The isolated compounds were tested for in-vitro cytotoxicity using Vero cells by 3-(4,5-dimethylthiazol-2-yl)-2,5-diphenyltetrazolium bromide (MTT) assay [28]. The Vero cell line was initiated from kidney of a normal adult African green monkey, Cercopitheus aethiops, obtained from Virology Laboratory, School of Biosciences and Biotechnology, Faculty of Science and Technology, UKM. Vero cells were maintained in DMEM, supplemented with 10\% FBS and cultured at $37{ }^{\circ} \mathrm{C}$ in a humidified $5 \% \mathrm{CO}_{2}$ incubator. The concentration of stock compound solution was $1.0 \mathrm{mg} / \mathrm{mL}$ prepared by dissolving $1 \mathrm{mg}$ compound in $50 \mu \mathrm{L}$ methanol and $950 \mu \mathrm{L} 5 \%$ FBS-DMEM. Sonicator was used to emulsify the compounds for $40 \mathrm{~min}$ before the two-fold dilutions made in $5 \%$ FBS-DMEM to produce a compound solution at concentrations of $0.5,0.25,0125$ and $0.0625 \mathrm{mg} / \mathrm{mL}$. Briefly, a total of $50 \mathrm{~mL}$ of cell suspension with different concentrations were added to each well in the 96-well micro-titer plates. As a positive control, each well from first to third wells was added with cells of $2.5 \times 10^{5}, 1.25 \times 10^{5}$ and $0.625 \times 10^{5}$ cells $/ \mathrm{mL}$. For the negative control $(100 \%$ cell death, $\left.\mathrm{LC}_{100}\right), 50 \mathrm{~mL}$ of DMEM without cells were added to the twelfth well. Cells of $2.5 \times 10^{5}$ cells $/ \mathrm{mL}$ were added into the fourth to eleventh wells. The plates were incubated for $48 \mathrm{~h}$ at $37{ }^{\circ} \mathrm{C}$ with $5 \% \mathrm{CO}_{2}$ until a monolayer is formed. A total of $50 \mu \mathrm{L}$ of test compound solution were placed in each well containing the monolayer cells and $50 \mu \mathrm{L}$ of phosphate buffered saline was added to each control cell well and negative control well $\left(\mathrm{LC}_{100}\right)$, and incubated for $24 \mathrm{~h}$ at $37{ }^{\circ} \mathrm{C}$ with $5 \% \mathrm{CO}_{2}$. After the incubation period, MTT $(20 \mu \mathrm{L}, 5 \mathrm{mg} / \mathrm{mL})$ was added into each well and the cells incubated for 2 to $4 \mathrm{~h}$, until a purple precipitate was clearly visible under a microscope, the medium together with MTT $(190 \mu \mathrm{L})$ was aspirated off from the wells, DMSO $(100 \mu \mathrm{L})$ was added and the plate shaken for $5 \mathrm{~min}$. The absorbance for each well was measured at $540 \mathrm{~nm}$ in a micro-titer plate reader and percentage of 
cell viability $(\mathrm{CV})$ was calculated manually using the formula: $\mathrm{CV}=\left[\left(\mathrm{Abs}_{\text {sample }}-\mathrm{Abs}_{\text {negative control }}\right) /\right.$ $\left.\left(\mathrm{Abs}_{\text {cell }}-\mathrm{Abs}_{\text {negative control }}\right)\right] \times 100$. A dose-response curve was plotted to enable the calculation of the concentration that kills $50 \%$ of the Vero cells $\left(\mathrm{LC}_{50}\right)$.

\subsection{Statistical Analysis}

Values expressed are means of the three replicate determinations \pm standard deviation. All statistical analyses were carried out using SPSS 16.00 for Windows. To determine whether there were any differences between activities of samples, variance analysis (one-way ANOVA) was applied to the results. Values of $p<0.05$ were considered as significant different $(\alpha=0.05)$.

\section{Conclusions}

The compounds $\mathbf{1}$ to $\mathbf{6}$ were found to be potent antioxidants, comparable in activity to the widely used synthetic antioxidant BHT in both assays. The activity was found to mostly increase with the number of phenolic units in the oligomer molecules. The non-toxic nature of all compounds $\mathbf{1}$ to $\mathbf{6}$ against normal (Vero) cells should merit further investigation to assess the effectiveness of these compounds in other biological activities including against other cell lines.

\section{Supplementary Materials}

Supplementary materials can be accessed at: http:/www.mdpi.com/1420-3049/17/8//9043/s1 .

\section{Acknowledgments}

We would like to thank the Ministry of Education Malaysia for PhD study leave of Norhayati Muhammad, Ministry of Higher Education Malaysia and Universiti Kebangsaan Malaysia (UKM) for financial support (Grant Codes: UKM-GUP-2011-205, UKM-OUP-KPB-31-156/2011 and UKM-DLP-2012-033). We are also very thankful to Centre for Research and Innovation Management, UKM for the technical support on LC-MS instrumentation. Thanks are also due to A. Hamid A. Hadi from the Chemistry Department, Faculty of Science, University of Malaya for kindly allowing us to use the polarimeter.

\section{References}

1. Xiao, K.; Zhang, H.-J.; Xuan, L.-J.; Zhang, J.; Xu, Y.-M.; Bai, D.-L. Stibenoids: Chemistry and bioactivities. Stud. Nat. Prod. Chem. 2008, 34, 453-646.

2. Shen, T.; Wong, X.-N.; Lou, H.-X. Natural stilbenes: An overview. Nat. Prod. Rep. 2009, 26, 916-935.

3. Lin, M.; Yao, C.-S. Natural oligostilbenes. Stud. Nat. Prod. Chem. 2006, 33, 601-644.

4. Quideau, S.; Deffieux, D.; Douat-Casassus, C.; Pouysegu, L. Plant polyphenols: Chemical properties, biological activities, and synthesis. Angew. Chem. Int. 2011, 50, 586-621. 
5. Morikawa, T.; Xu, F.; Matsuda, H.; Yoshikawa, M. Structures of novel norstilbene dimer, longusone $\mathrm{A}$, and three new stilbene dimers, longusols $\mathrm{A}, \mathrm{B}$, and $\mathrm{C}$, with antiallergic and radical scavenging activities from Egyptian natural medicine Cyperus longus. Chem. Pharm. Bull. 2010, $58,1379-1385$.

6. Ito, T.; Tanaka, T.; Nakaya, K.; Iinuma, M.; Takahashi, Y.; Naganawa, H.; Ohyama, M.; Nakanishi, Y.; Bastow, K.F.; Lee, K.-H. A new resveratrol octamer, vateriaphenol A, in Vateria indica. Tetrahedron Lett. 2001, 42, 5909-5912.

7. He, S.; Wu, B.; Pan, Y.; Jiang, L. Stilbene oligomers from Parthenocissus laetevirens: Isolation, biomimetic synthesis, absolute configuration, and implication of antioxidative defense system in the plant. J. Org. Chem. 2008, 73, 5233-5241.

8. He, S.; Jiang, L.; Wu, B.; Li, C.; Pan, Y. Chunganenol: An unusual antioxidative resveratrol hexamer from Vitis chunganensis. J. Org. Chem. 2009, 74, 7966-7969.

9. Nitta, T.; Arai, T.; Takamatsu, H.; Inatomi, Y.; Murata, H.; Iinuma, M.; Tanaka, T.; Ito, T.; Asai, F.; Ibrahim, I.; et al. Antibacterial activity of extracts preepared from tropical and subtropical plants on Methicillin-Resistant Staphylococcus aureus. J. Health Sci. 2002, 48, 273-276.

10. Chung, E.Y.; Roh, E.; Kwak, J.A.; Lee, H.S.; Lee, C.K.; Han, S.B.; Kim, Y. Alpha-viniferin suppresses the signal transducer and activation of transcription-1 (STAT-1)-inducible inflammatory genes in interferen-gamma-stimulated macrophages. J. Pharmacol. Sci. 2010, 112, 405-414.

11. Oshima, Y.; Namao, K.; Kamijou, A.; Matsuoko, S.; Nakano, M.; Terao, K.; Ohizumi, Y. Powerful hepatoprotective and hepatotoxic plant oligostilbenes, isolated from the oriental medicinal plant Vitis coignetiae (Vitaceae). Experientia 1995, 51, 63-66.

12. Ito, T.; Akao, Y.; Yi, H.; Ohgucgi, K.; Matsumoto, K.; Tanaka, T.; Iinuma, M.; Nozawa, Y. Antitumor effect of resveratrol oligomers against human cancer cell lines and the molecular mechanism of apoptosis induced by vaticanol C. Carcinogenesis 2003, 24, 1489-1497.

13. Jiang, L.; He, S.; Sun, C.; Pan, Y. Selective ${ }^{1} \mathrm{O}_{2}$ quenchers, oligostilbenes, from Vitis wilsonae: Structural identification and biogenetic relationship. Phytochemistry 2012, 77, 294-303.

14. Symington, C.F. Foresters' Manual of Dipterocarps: Malayan Forest Records No. 16, 2nd ed.; Forest Research Institute and Malaysian Nature Society: Kuala Lumpur, Malaysia, 2004; pp. 175-197.

15. Cheung, H.T.; Yan, T.C. Constituents of Dipterocarpaceae resins IV. Triterpenes of Shorea acuminata and Shorea resina-nigra. Aust. J. Chem. 1972, 25, 2003-2012.

16. Hirano, Y.; Kondo, R.; Sakai, K. Novel stilbenoids isolated from the heartwood of Shorea laeviforia. J. Wood Sci. 2003, 49, 53-58.

17. Ito, T.; Tanaka, T.; Ido, Y.; Nakaya, K.-I.; Iinuma, M.; Riswan, S. Stilbenoids isolated from stem bark of Shorea hemsleyana. Chem. Pharm. Bull. 2000, 48, 1001-1005.

18. Ito, T.; Furusawa, M.; Iliya, I.; Tanaka, T.; Nakaya, K.-I.; Sawa, R.; Kubota, Y.; Takahashi, Y.; Riswan, S.; Iinuma, M. Rotational isomerism of a resveratrol tetramer, shoreaketone, in Shorea uliginosa. Tetrahedron Lett. 2005, 46, 3111-3114.

19. Tanaka, T.; Ito, T.; Nakaya, K.; Iinuma, M.; Riswan, S. Oligostilbenoids in stem bark of Vatica rassak. Phytochemistry 2000, 54, 63-69.

20. Kawabata, J.; Fukushi, E.; Hara, M.; Mizutani, J. Detection of connectivity between equivalent carbons in a $\mathrm{C} 2$ molecule using isotopomeric asymmetry: Identification of hopeaphenol in Carex pumila. Magn. Reson. Chem. 1992, 30, 6-10. 
21. Karplus, M. Vicinal proton coupling in nuclear magnetic resonance. J. Am. Chem. Soc. 1963, 85, 2870-2871.

22. Oshima, Y.; Ueno, Y.; Hikino, H.; Yang, L.L.; Yen, K.Y. Ampelopsins A, B and C, new oligostilbenes of Ampelopsis brevipedunculata var. hancei. Tetrahedron 1990, 46, 5121-5126.

23. Tanaka, T.; Ito, T.; Ido, Y.; Son, T.-K.; Nakaya, K.; Iinuma, M.; Ohyama, M.; Chelladurai, V. Stilbenoids in the stem bark of Hopea parviflora. Phytochemistry 2000, 53, 1015-1019.

24. Siramon, P.; Ohtani, Y. Antioxidative and antiradical activities of Eucalyptus camaldulensis leaf oils from Thailand. J. Wood Sci. 2007, 53, 498-504.

25. Das, A.; Trousdale, M.D.; Ren, S.; Lien, E.J. Inhibitin of herpes simplex virus type 1 and adenovirus type 5 by heterocyclic Schiff bases of aminohydroxyguanidine tosylate. Antivir. Res. 1999, 44, 201-208.

26 Miliauskas, G.; Venskutonis, P.R.; van Beek, T.A. Screening of radical scavenging activity of some medicinal and aromatic plant extracts. Food Chem. 2004, 85, 231-237.

27. Jayaprakasha, G.K.; Singh, R.P.; Sakariah, K.K. Antioxidant activity of grape seed (Vitis vinifera) extracts on peroxidation models in vitro. Food Chem. 2001, 73, 285-290.

28. Fazari, G.M.; Azilawaty, A.; Nazlina, I.; Yaacob, W.A. Cytotoxic effect and anti-MRSA activity of methanolic extracts of Phyllanthus gracilipes and Phyllanthus columnaris. Sains Malays. 2011, $40,457-466$.

Sample Availability: Samples of the compounds 1-6 are available from the authors.

(C) 2012 by the authors; licensee MDPI, Basel, Switzerland. This article is an open access article distributed under the terms and conditions of the Creative Commons Attribution license (http://creativecommons.org/licenses/by/3.0/). 